\title{
TNFa and IL-17 cooperatively stimulate glucose metabolism and growth factor production in human colorectal cancer cells
}

Daniel S Straus

\begin{abstract}
Background: Inflammation is a well-known etiological factor for colorectal cancer, but mechanisms underlying the linkage between inflammation and cancer are incompletely understood. We hypothesized that two pro-inflammatory cytokines, TNFa and IL-17, might play a role in promoting colorectal carcinogenesis. Aerobic glycolysis is a metabolic adaptation that promotes the survival/proliferation of cancer cells. Paracrine signaling between tumor cells and cancerassociated fibroblasts also plays a role in carcinogenesis.

Methods: The effect of TNFa and IL-17 on aerobic glycolysis and growth factor production in cultured human colorectal cancer cells was investigated. Glucose utilization and lactate production were quantified by measuring the disappearance of glucose and appearance of lactate in the culture medium. Glucose transporter and glycolytic enzyme expression levels were measured by immunoblotting.

Results: TNFa and IL-17 cooperatively stimulated glycolysis in HT-29, T84, Caco-2 and HCT116 colorectal cancer cells. Treatment of HT-29 cells with TNFa plus IL-17 also increased the expression of HIF-1a and c-myc, two factors know to induce the transcription of genes encoding components of the glycolytic pathway. To further investigate mechanisms for cytokine-stimulated glycolysis, the effects of TNFa and IL-17 on expression of six members and one regulator of the glycolytic pathway were investigated. TNFa and IL-17 cooperatively increased the expression of the glucose transporter SLC2A1 and hexokinase-2 but did not regulate expression of glucose transporter SLC2A3, enolase-1, pyruvate kinase M2, lactate dehydrogenase A, or 6-phoshofructo-2-kinase/fructose-2,6-bisphosphatase-3 (PFKFB3). Experiments with inhibitors indicated that HIF-1 a played a role in induction of SLC2A1 and that the transcription factor NF-KB played a role in induction of hexokinase-2 by TNFa and IL-17. TNFa and IL-17 also synergistically stimulated production by HT-29 cells of a growth factor that simulated proliferation/survival of NIL8 fibroblastic cells. The activity of this factor was not specifically inhibited by the EGFR inhibitor AG1478, indicating that it is not an EGFR ligand.
\end{abstract}

Conclusions: Chronic inflammation is known to promote colorectal tumorigenesis. The pro-inflammatory cytokines TNFa and IL-17 may contribute to this effect by stimulating glycolysis and growth factor production in colorectal cancer cells.

Keywords: Colorectal cancer, TNFa, IL-17, HIF-1a, Aerobic glycolysis, NF-KB, SLC2A1, Hexokinase-2

Correspondence: straus@ucr.edu

Biomedical Sciences Division, School of Medicine, University of California,

Riverside, CA 92521, USA 


\section{Introduction}

Considerable evidence has accumulated recently implicating inflammation as a causative factor in tumorigenesis [1,2]. There were an estimated 142,570 new cases of colorectal cancer (CRC) in the US in 2010, and CRC is the second most common cause of cancer death in the US [3]. A role for inflammation in causation of CRC is well documented $[4,5]$. For example, patients with inflammatory bowel disease (ulcerative colitis and Crohn's disease) have a greatly increased risk for colorectal cancer $[4,5]$. Moreover, non-steroidal anti-inflammatory drugs such as aspirin and cyclooxygenase inhibitors have been shown to decrease the occurrence of adenomatous polyps [6]. However, despite clear evidence implicating inflammation in causation of CRC and other cancers, molecular mechanisms underlying this phenomenon are incompletely understood.

Much interest has focused recently on metabolic abnormalities in cancer cells. Among these, aerobic glycolysis (i.e. the Warburg effect) is a metabolic adaptation that promotes the survival/proliferation of cancer cells [7-9]. Increased activity of the glycolytic pathway provides biosynthetic substrates required by proliferating cells, inhibits apoptosis, and results in increased production of L-lactate, which exerts pro-carcinogenic effects [7-10]. While increased expression/activity of transcription factors HIF- $1 \alpha$ and c-myc is thought to play an important role in the increased glycolysis in cancer cells, the underlying mechanisms are not completely understood [11-13]. HIF-1 $\alpha$ is a master regulator of genes encoding components of the glycolytic pathway $[11,12]$, and c-myc also positively regulates some of these same genes [13-15]. High activity of the PI3 kinase-AKT signaling pathway in cancer cells appears to be causally related to the increased expression of HIF- $1 \alpha$ and c-myc [13]. Growth factors such as EGF and insulin increase the expression of HIF-1 $\alpha[16,17]$, and a few studies have implicated cytokines as regulators of HIF-1 $\alpha$ [18-20].

The two cytokines, TNFo and interleukin 17 (IL-17, also called IL-17A), play an important role in both acute and chronic inflammation. The importance of TNF $\alpha$ in inflammatory bowel disease is illustrated by the efficacy of anti-TNFo monoclonal antibodies in treating Crohn's disease and ulcerative colitis [21]. In the gut, IL-17 is produced by a number of innate immune cells including innate lymphoid cells (ILC) $[22,23]$. In the adaptive immune response, IL-17 is produced by Th17 cells [24]. IL-17 expression is increased in inflammatory bowel disease [25], and tumor-infiltrating Th17 cells are found in human colorectal cancer and are associated with shortened disease-free survival $[26,27]$. Recent studies with mouse models have also revealed a role for IL-17 signaling in the development of colorectal tumors [28]. TNF $\alpha$ is produced in colorectal tumors by infiltrating macrophages, and higher TNF $\alpha$ expression is correlated with increased tumor diameter [29]. Thus, TNF $\alpha$ and IL-17 are frequently both present in acute and chronic inflammation, and both have been linked to colorectal cancer. The combined effect of the two cytokines on tumor cell metabolism and growth is therefore of considerable interest.

Previous studies of the regulation of gene expression by TNF $\alpha$ plus IL-17 have shown cooperative effects, in which TNF $\alpha$ induces transcription of target genes while IL-17 stabilizes their mRNAs [30,31]. The transcription factor NF- $\mathrm{kB}$ is an important mediator of transcriptional effects of TNF $\alpha$ in target cells including colorectal cancer cells [30]. Moreover, IL-17 synergizes with TNFa to induce expression of a number of genes including those encoding chemokines such as CXCL1, CXCL8, and CCL20 [30]. Major mechanisms for this effect are activation of the canonical NF- $\mathrm{kB}$ signaling pathway by TNF $\alpha$ resulting in increased gene transcription, and IL-17mediated stabilization of mRNAs [30,31].

Heterotypic interactions between tumor cells and stromal cells in the surrounding microenvironment play an essential role in tumorigenesis [32]. Stromal cancerassociated fibroblasts (CAF) and tumor cells form a reciprocal positive feedback loop, in which the tumor cells produce factors that promote activation, proliferation and chemotaxis of CAF, which in turn produce factors that enhance tumor cell proliferation [33-35]. Inhibition of CAF signaling pathways thus inhibits tumorigenesis [36].

In the present study we examined the effect of TNF $\alpha$ and IL-17 on glycolysis and growth factor production in colorectal cancer cells. The results indicate that the two cytokines cooperate to increase activity of the glycolytic pathway and to increase production of growth factor(s) that enhance the proliferation/survival of fibroblastic cells.

\section{Results}

The effect of TNF $\alpha$, IL-17, and TNF $\alpha$ plus IL-17 on glucose utilization in HT-29 human colorectal cancer cells is shown in Figure 1A. Treatment with TNF $\alpha$ modestly stimulated glucose utilization by the HT-29 cells. Treatment with IL-17 alone had no effect, but IL-17 synergized with TNF $\alpha$ to strongly stimulate glucose utilization. TNF $\alpha$ and IL-17 also cooperatively stimulated glucose utilization by three other human colorectal cancer cell lines, HCT116, T84 and Caco-2 (Figure 1B,C,D). As observed with the HT-29 cells, the effect of TNFa plus IL-17 was synergistic in T84 and Caco-2 cells whereas in HCT116 cells the effect of TNFa plus IL-17 was roughly additive. The effect of TNF $\alpha$ and IL-17 on production of L-lactate by HT-29 cells is shown in Figure 1E. TNFo and IL-17 synergistically stimulated lactate production, indicating that the increased glucose utilization elicited by TNF $\alpha$ 

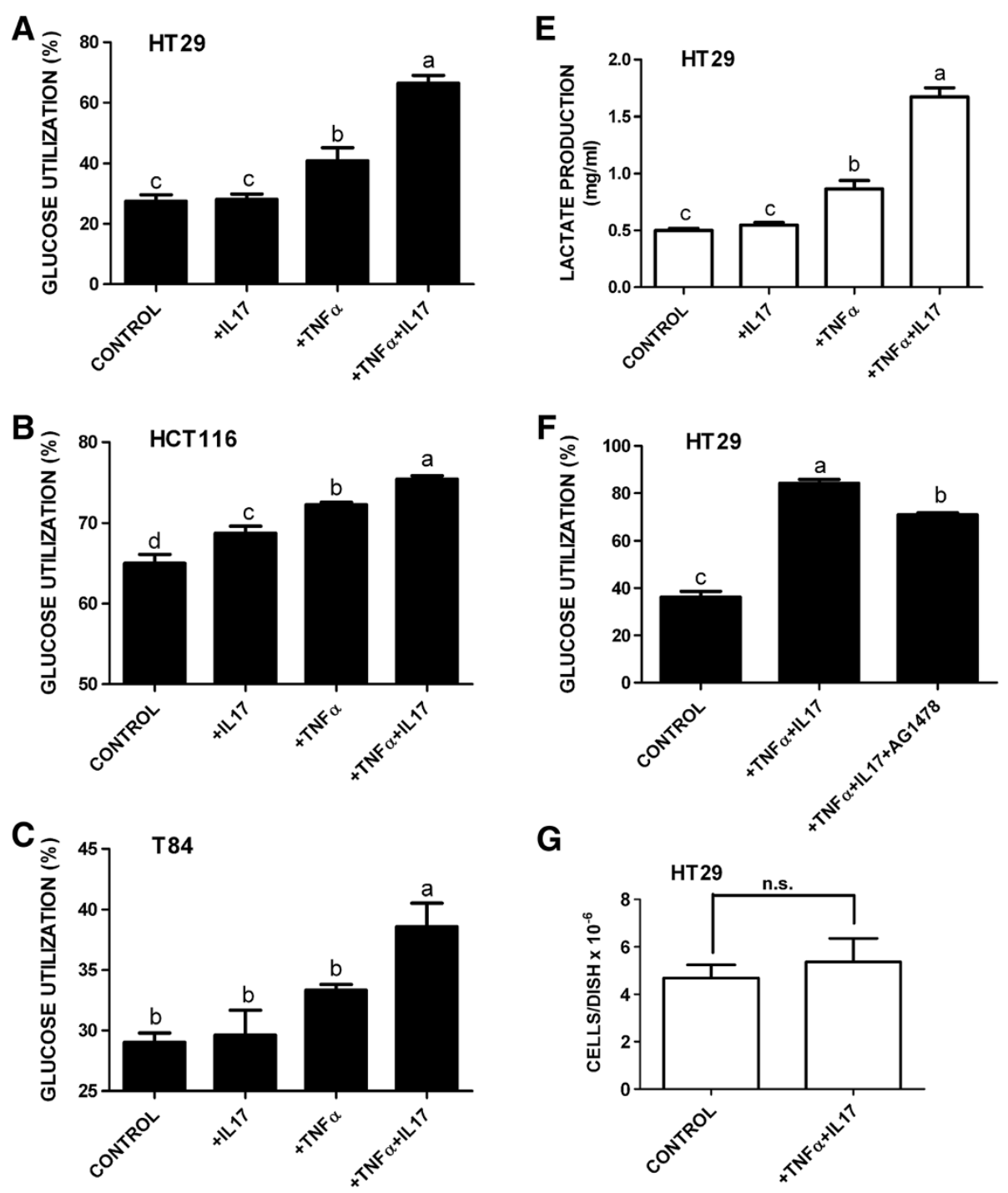

G
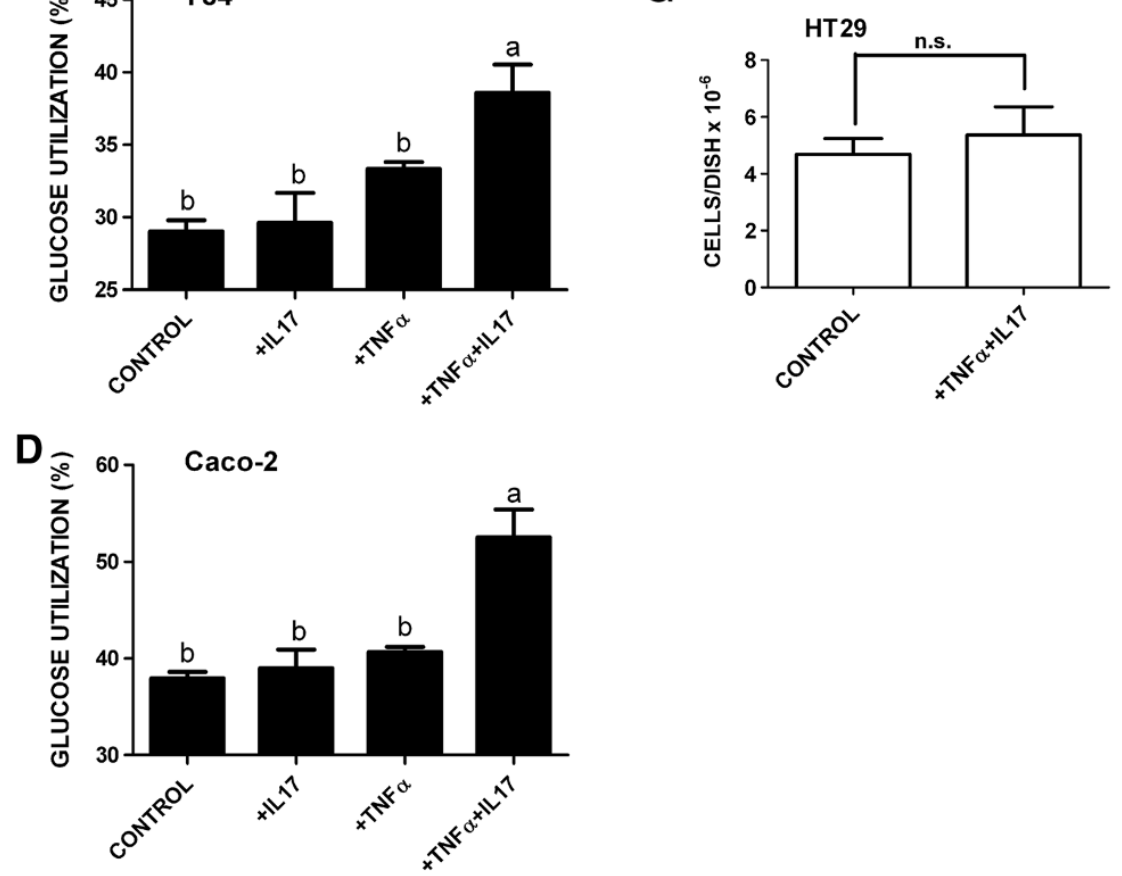

Figure 1 Effect of TNFa $(25 \mathrm{ng} / \mathrm{ml})$ and IL-17 $(50 \mathrm{ng} / \mathrm{ml})$ on glucose utilization and lactate production of human colorectal cancer cell lines. Colorectal cancer cell lines (A, HT-29; B, HCT116; C, T84, and D, Caco-2) were treated for $24 \mathrm{~h}$ with cytokines as shown. The medium was harvested and assayed for D-glucose. Glucose utilization was expressed as percentage decrease of glucose in the medium. E. Production of L-lactate by HT-29 cells. Cells were treated with cytokines as shown. The medium was harvested and assayed for L-lactate. F. Effect of EGFR-selective tyrosine protein kinase inhibitor AG1478 on cytokine-stimulated glucose utilization by HT-29 cells. Cells were treated for $24 \mathrm{~h}$ with cytokines as shown, with or without AG1478 (1 MM). Culture medium samples were then assayed for D-glucose as in panels A-D. G. Effect of TNFa plus IL-17 on HT-29 cell numbers. Cultures were treated with vehicle or cytokines for $24 \mathrm{~h}$, and cells were then harvested and counted. In panels A-F, each bar represents the mean \pm SE of three replicate cultures; in panel $\mathrm{G}$ each bar represents the mean $\pm \mathrm{SE}$ of six replicate cultures. Means with different letters were significantly different, $P<0.05$. In panel $G$, n.s. $=$ not significant based on $t$-test. 
plus IL-17 reflected metabolism of glucose through to the end product of the glycolytic pathway, L-lactate.

Treatment of HT-29 cells with TNF $\alpha$ transactivates the EGF receptor (EGFR), and this effect is augmented by IL-17 [30,37]. Therefore, it was possible that the effect of the two cytokines on glucose metabolism might be mediated by EGFR signaling. In support of this notion, EGF has been shown to simulate glucose metabolism in other cells [38,39]. The EGFR-selective receptor tyrosine kinase inhibitor AG1478 (1 $\mu \mathrm{M})$, which completely inhibits EGFR signaling at this high concentration [40], only modestly inhibited the stimulation of glucose metabolism by TNF $\alpha$ plus IL-17 (Figure 1F). Thus signaling via pathway(s) other than the EGFR pathway appears to be involved in the regulation of glucose metabolism. Treatment of HT-29 cells for 24 h with TNF $\alpha$ plus IL-17 did not significantly affect cell numbers (Figure 1G).

Stimulation of glycolysis in cancer cells under hypoxic conditions is thought to be mediated largely by activation of the transcription factor HIF- $1 \alpha$, a master regulator of genes encoding a number of components of the glycolytic pathway $[11,12]$. The transcription factor c-myc also positively regulates several of these genes [13-15]. The effect of a $4 \mathrm{~h}$ treatment with TNF $\alpha$, IL-17, or TNF $\alpha+$ IL-17 on expression of HIF- $1 \alpha$ and c-myc protein is shown in Figure 2. IL-17 synergized with TNF $\alpha$ to increase expression of HIF- $1 \alpha$ and also cooperated with TNF $\alpha$ to increase the expression of c-myc (Figure 2).

The PI3K-AKT signaling pathway has been reported to play a major role in mediating the regulation of HIF-1 $\alpha$ expression in cancer [13] and in response to growth factors $[16,17]$. We therefore considered the possibility that PI3K-AKT signaling might mediate the effect of TNF $\alpha+$ IL-17 on HIF- $1 \alpha$ expression. TNF $\alpha+$ IL-17 dramatically increased the phosphorylation of AKT in HT-29 cells, with a maximal effect observed at 15 min (Figure 3A). This effect was entirely blocked by the PI3K inhibitor
LY294002 and substantially inhibited by the EGFR inhibitor AG1478 (Figure 3B), but was unaffected by the Src inhibitor SU6656 Figure 3C. This result suggested that transactivation of EGFR contributed to PI3K pathway activation in response to TNF $\alpha+\mathrm{IL}-17$, but that Src pathway signaling, which sometimes mediates EGFR transactivation [41], was not involved. TNF $\alpha$ strongly increased AKT phosphorylation (Figure 3D,E). In contrast, IL-17 had a very modest effect that did not attain statistical significance, and it also did not significantly augment TNF $\alpha$-stimulated AKT phosphorylation (Figure 3D,E). Therefore, activation of the PI3K signaling pathway might contribute to TNF $\alpha$-mediated stimulation of HIF-1 $\alpha$ expression, but it did not account for the cooperative effect of IL-17 in combination with TNF $\alpha$ shown in Figure 2.

The results shown in Figure 2 suggested that the effect of TNF $\alpha$ and IL-17 on glycolysis might be mediated by increased expression/activation of HIF- $1 \alpha$ and c-myc, leading to transcriptional induction of genes encoding components of the glycolytic pathway. To test this idea, we examined the effect of TNF $\alpha$ and IL-17 on expression of six components of the pathway: the glucose transporters SLC2A1 (Glut1) and SLC2A3 (Glut3), hexokinase-2 (HK2), enolase-1 (ENO1), pyruvate kinase M2 (PKM2), and lactate dehydrogenase A (LDHA). These correspond to the first two steps of the glycolytic pathway (glucose transport and HK2), and the last three steps (ENO1, PKM2, and LDHA). We also examined the effect of TNF $\alpha$ on expression of 6-phoshofructo-2-kinase/ fructose-2,6-bisphosphatase-3 (PFKFB3), which produces fructose-2,6-bisphosphate, a major allosteric regulator of the glycolytic pathway enzyme 6-phosphofructo-1-kinase [42]. The genes encoding all seven proteins are targets of transcriptional activation by HIF- $1 \alpha[12,42-44]$, and three of them, (SLC2A1, HK2, and LDHA) are also well documented targets of c-myc [13-15]. The results (Figure 4A,B) indicated that in cells treated for $12 \mathrm{~h}, \mathrm{TNF} \alpha$ and IL-17

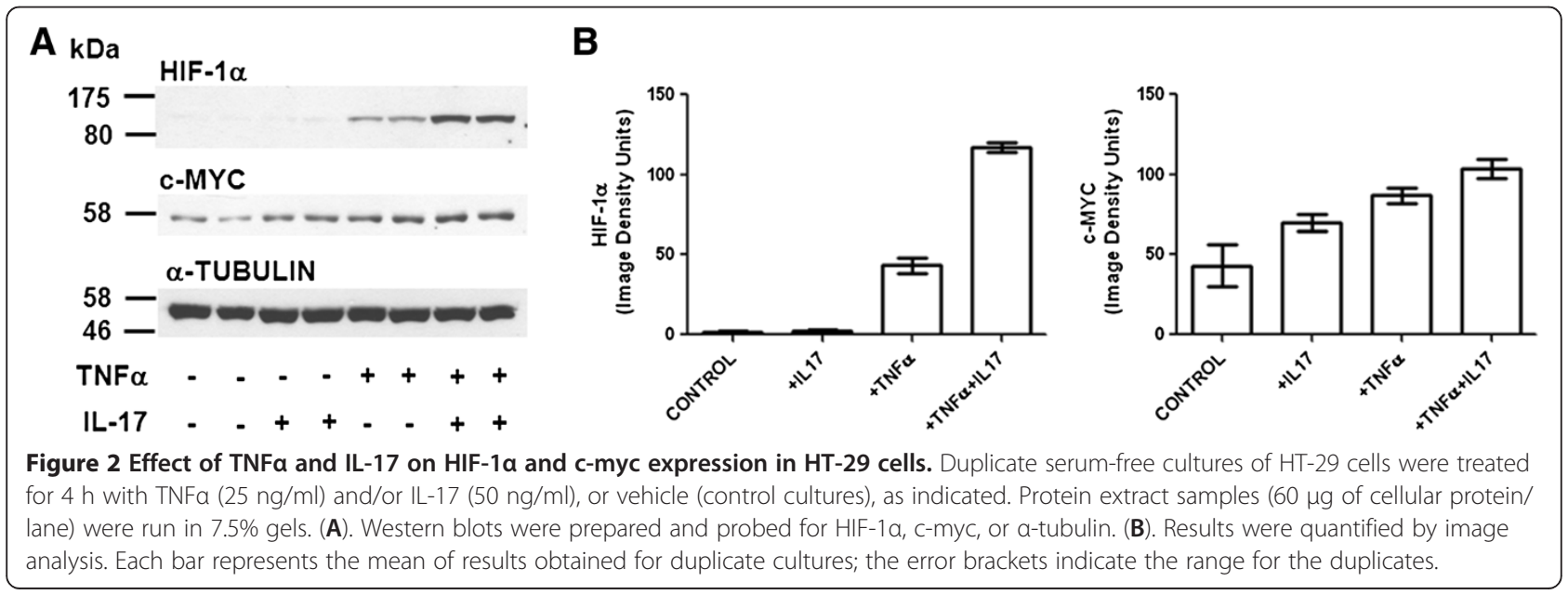


A
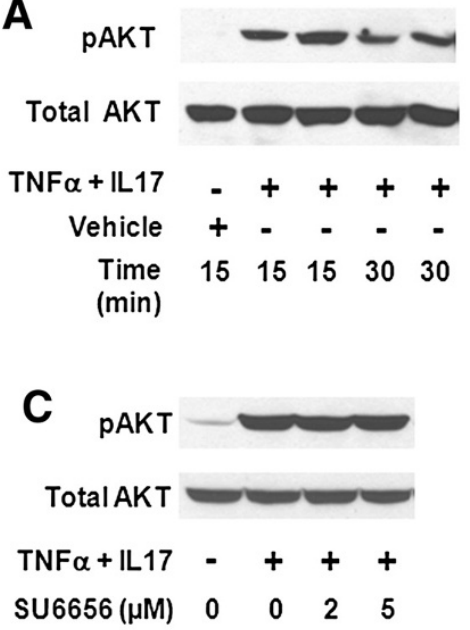

B

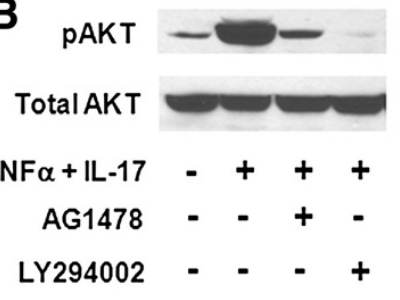

D

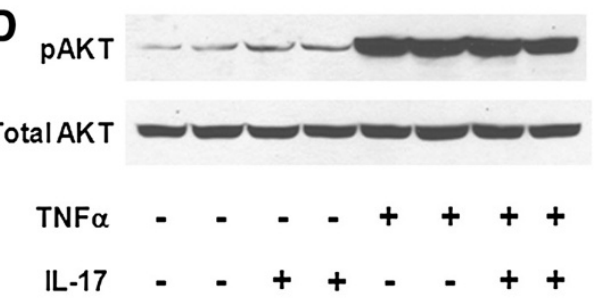

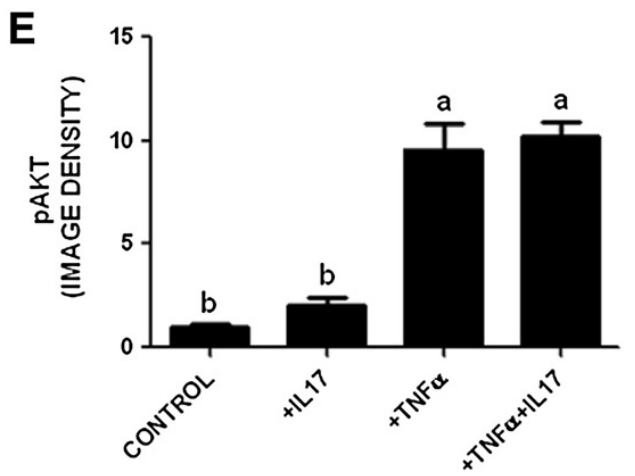

Figure 3 Effect of TNFa and IL-17 on AKT phosphorylation on Ser473. Cultures of HT-29 cells were incubated in serum-free medium for $24 \mathrm{~h}$ and then treated with vehicle, TNFa $(25 \mathrm{ng} / \mathrm{ml}), \mathrm{LL}-17(50 \mathrm{ng} / \mathrm{ml})$, or TNFa + IL-17. Western blots were prepared and probed with rabbit monoclonal antibody specific for phospho-AKT (Ser473) or whole AKT. A. Time course for AKT phosphorylation. In subsequent experiments (B - E) cells were

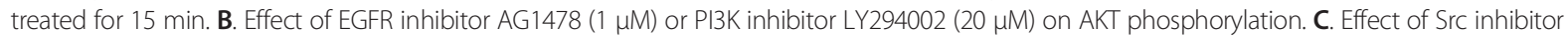
SU6656 on AKT phosphorylation. D. Effect of vehicle, TNFa, IL-17, or TNFa + IL-17 on AKT phosphorylation. E. Effect of vehicle, TNFa, IL-17, or TNFa + IL-17 on AKT phosphorylation, quantified by image analysis. Each bar represents the mean \pm SE of four replicate cultures. Means with different letters were significantly different, $P<0.05$.

cooperatively increased the expression of SLC2A1 and $\mathrm{HK} 2$, but did not regulate the expression of SLC2A3, ENO1, PKM2, LDHA, or PFKFB3. In the case of SLC2A1, IL-17 alone had no effect, but it gave a small but reproducible increase in the induction by TNF $\alpha$. In the case of HK2, IL17 and TNF $\alpha$ both increased expression, and the two cytokines together had a greater effect than either alone (Figure 4A,B). Very similar results were obtained with cells treated for $24 \mathrm{~h}$ (Figure 4C).

Chetomin is a low molecular weight compound that inhibits transcriptional activation by HIF- $1 \alpha$ by blocking its binding of the co-activator p300 [45]. The effect of chetomin on cytokine-induced lactate production and expression of SLC2A1 and HK2 is shown in Figure 5. Chetomin partially inhibited the stimulation of lactate production by TNF $\alpha+$ IL-17 in a dose-dependent manner (Figure 5A). In another experiment performed in quadruplicate, $200 \mathrm{nM}$ chetomin inhibited lactate production by $24 \%$ in cells stimulated with TNF $\alpha+$ IL-17, and a commensurate inhibition of glucose utilization was also observed (Figure 5B). A partial inhibition by chetomin of cytokine-stimulated SLC2A1 expression was also observed (Figure 5C,D). The effective chetomin dose range of $50-200 \mathrm{nM}$ was very similar to that required for inhibition of HIF- $1 \alpha$ action in other human cancer cell lines [46]. In contrast chetomin had little or no effect on HK2 expression (Figure 5C,D). Finally, chetomin had no significant effect on cell numbers under the conditions of our experiments (Figure 5E).

$\mathrm{NF}-\mathrm{kB}$ plays a major role in mediating transcriptional induction of genes encoding several chemokines in cells treated with TNF $\alpha+$ IL-17 [30,31]. Several studies have documented that TNF $\alpha$ activates NF-kB in HT-29 and other human colorectal cancer cell lines $[30,47,48]$. The 

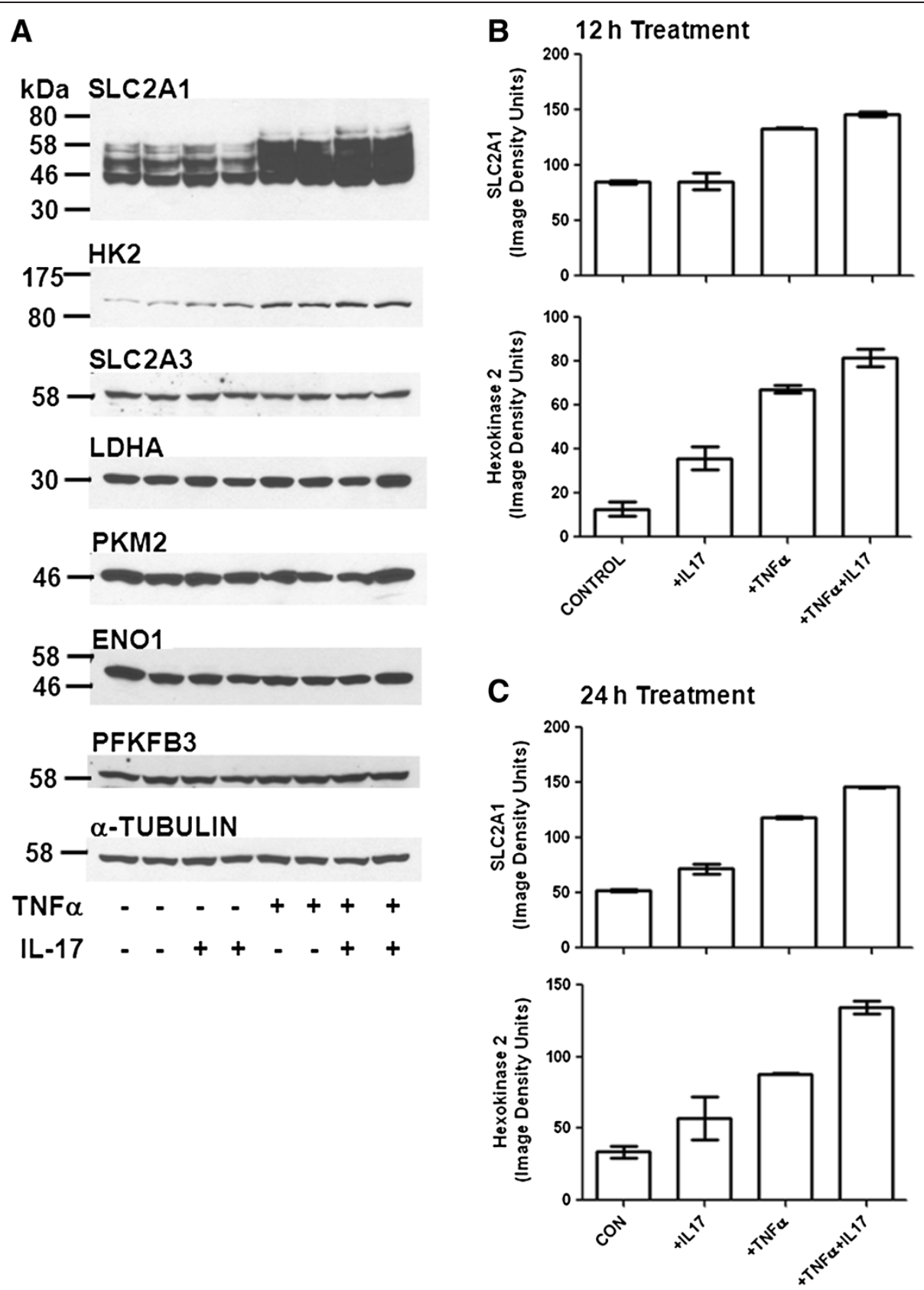

Figure 4 Effect of TNFa and IL-17 on expression of glycolytic pathway components. Duplicate serum-free cultures of HT-29 cells were treated for $12 \mathrm{~h}$ or $24 \mathrm{~h}$ with TNFa $(25 \mathrm{ng} / \mathrm{ml})$ and/or IL-17 $(50 \mathrm{ng} / \mathrm{ml})$, or vehicle (control cultures), as indicated. Protein extract samples $(60 \mu \mathrm{g}$ of cellular protein/lane) were run in $7.5 \%$ gels. (A). Western blots were prepared with extracts of cells treated for $12 \mathrm{~h}$ and probed for SLC2A1, HK2, SLC2A3, LDHA, PKM2, ENO1, PFKFB3, and a-tubulin. (B). Results for SLC2A1 and HK2 were quantified by image analysis. Each bar represents the mean of results obtained for duplicate cultures; the error brackets indicate the range for the duplicates. (C). Western blots were prepared for HT-29 cells treated for $24 \mathrm{~h}$, and the results for SLC2A1 and HK2 were quantified by image analysis. Each bar represents the mean of results obtained for duplicate cultures; the error brackets indicate the range for the duplicates.

protein kinase IKK $\beta$ is a key component of the pathway for NF-kB activation by TNF $\alpha$ [49]. To investigate the possibility that NF- $\mathrm{kB}$ might participate in the induction of SLC2A1 and/or HK2, the effect of the IKK $\beta$-selective inhibitor TPCA-1 [50] on cytokine-induced lactate production and expression of SLC2A1 and HK2 was tested.
The results indicated that TPCA-1 strongly inhibited the cytokine-stimulated component of lactate production by HT-29 cells (Figure 6A). A similar strong inhibition of cytokine-stimulated HK2 expression was also observed (Figure 6B,C). In contrast TPCA-1 had little or no effect on SLC2A1 expression (Figure 6B,C). The combined 


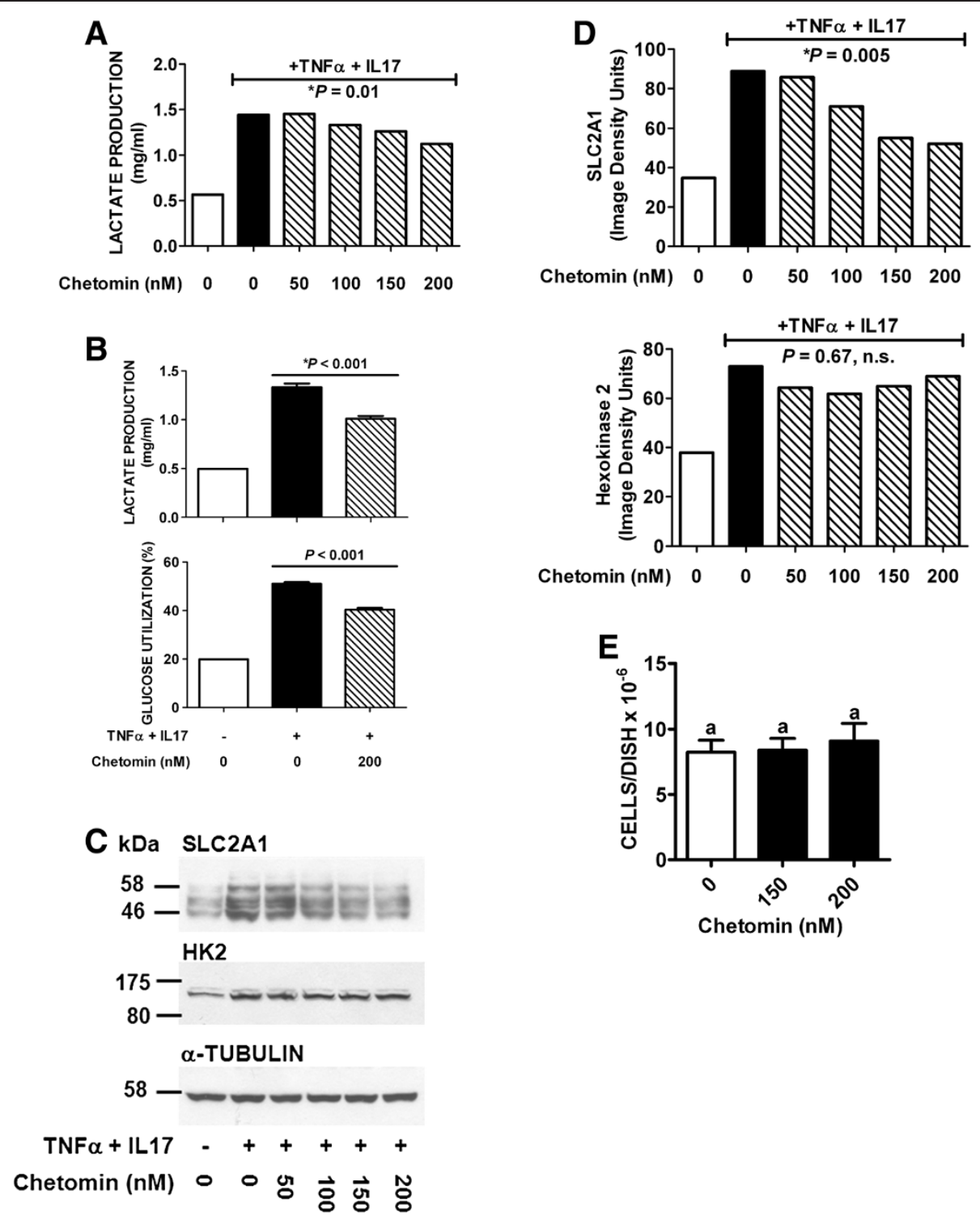

Figure 5 Inhibition by chetomin of cytokine-stimulated lactate production, glucose utilization, and expression of SLC2A1 and HK2 by HT-29 cells. Serum-free cultures of HT-29 cells were pre-treated with chetomin or vehicle for $4 \mathrm{~h}$, and TNFa $(25 \mathrm{ng} / \mathrm{ml})+\mathrm{lL}-17$ (50 ng/ml) was then added to some of the cultures for an additional $12 \mathrm{~h}$. Medium samples were then collected for lactate and glucose assays, and protein extract samples of cell monolayers (30 $\mathrm{\mu g}$ of cellular protein/lane) were run in $7.5 \% \mathrm{gels}$. (A). Effect of increasing concentrations of chetomin on lactate production. Analysis of the data by linear regression showed a significant dose-dependent inhibition of lactate production by chetomin, $P=0.01$. (B). Inhibition of lactate production (top) and glucose utilization (bottom) by $200 \mathrm{nM}$ chetomin. Solid black and cross-hatched bars represent the means \pm SE of assays performed with medium samples from quadruplicate cultures. Chetomin significantly inhibited lactate production and glucose utilization in cells stimulated by TNFa + IL-17, P<0.001. (C). Western blots of cell extract proteins were probed for SLC2A1, HK2, or a-tubulin. (D). Results of Western blots shown in panel $C$ were quantified by image analysis. Analysis of the data by linear regression showed significant dose-dependent inhibition by chetomin of SLC2A1 $(P=0.005)$ but not HK2 ( $P=0.67$, n.s.) expression. (E). Effect of chetomin on HT-29 cell numbers. Cultures were treated with vehicle or chetomin for $16 \mathrm{~h}$, and cells were then harvested and counted. Each bar represents the mean \pm SD of results obtained with six cultures. Bars with different letters were significantly different, $P<0.05$.

results presented in Figures 5 and 6 suggest that HIF- $1 \alpha$ plays a role in the induction of SLC2A1 by TNF $\alpha+$ IL-17, and that NF- $\mathrm{kB}$ plays a role in the induction of HK2.

Paracrine signaling between tumor cells and tumorassociated stromal cells plays an important role in carcinogenesis. We next used the NIL8 fibroblastic cell line to determine whether TNFa and IL-17 regulated production of growth factors that are active in fibroblastic cells. The NIL8 cells have been shown previously to respond to a variety of growth factors that stimulate the proliferation of fibroblasts [51-53]. The results (Figure 7A) demonstrated that TNF $\alpha$ stimulated growth factor release 

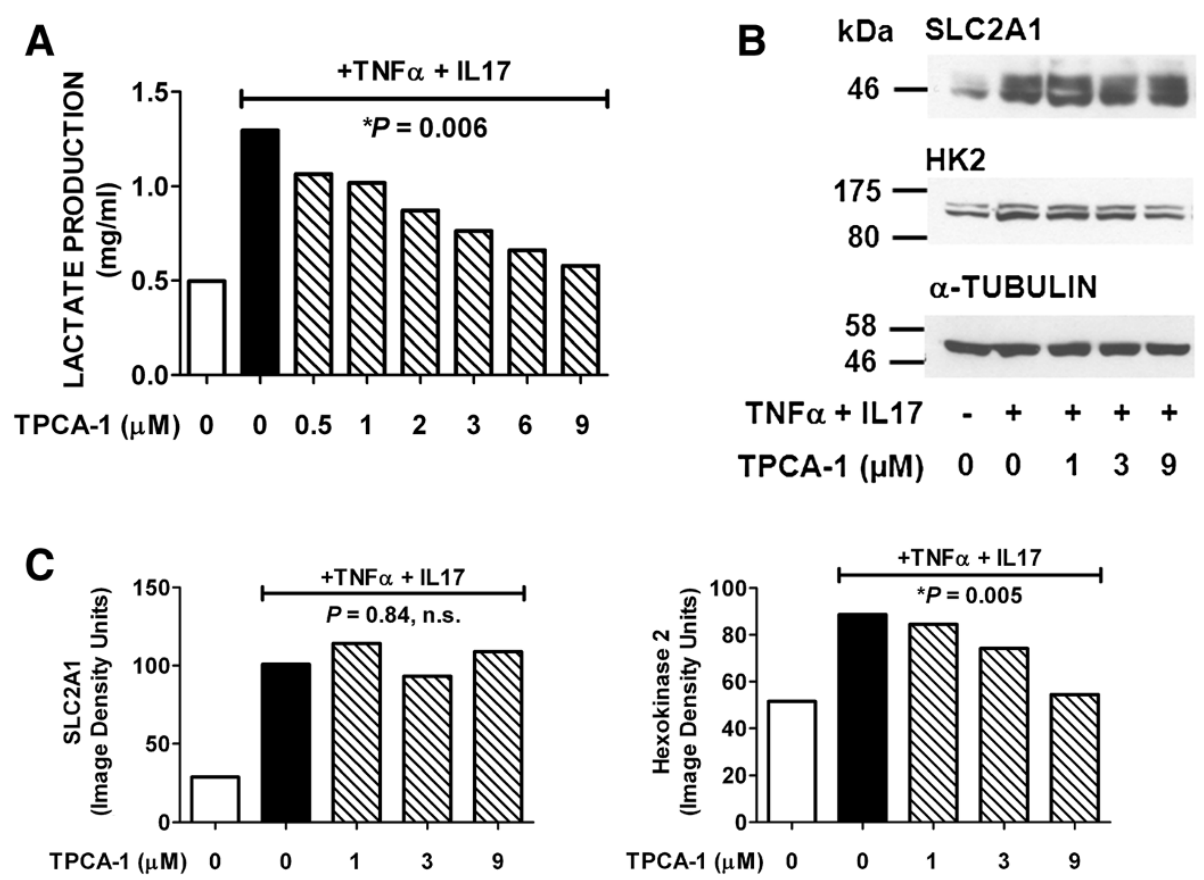

Figure 6 Inhibition by TPCA-1 of cytokine-stimulated lactate production and expression of SLC2A1 and HK2 by HT-29 cells. Serum-free cultures of HT-29 cells were treated for $12 \mathrm{~h}$ with TNFa $(25 \mathrm{ng} / \mathrm{ml})+\mathrm{IL}-17(50 \mathrm{ng} / \mathrm{ml})$, in the presence of TPCA-1 or vehicle, as shown. Medium samples were then collected for lactate assays, and protein extract samples of cell monolayers (30 $\mu \mathrm{g}$ of cellular protein/lane) were run in 7.5\% gels. (A). Effect of increasing concentrations of TPCA-1 on lactate production. Analysis of the data by linear regression showed a significant dosedependent inhibition of lactate production by TPCA-1, $P=0.006$. (B). Western blots of cell extract proteins were probed for SLC2A1, HK2, or a-tubulin. (C). Results of Western blots shown in panel B were quantified by image analysis. Analysis of the data by linear regression showed significant dosedependent inhibition by TPCA-1 of HK-2 ( $P=0.005)$ but not SLC2A1 $(P=0.84$, n.s.) expression.

by HT-29 cells. IL-17 alone had no effect but enhanced the effect of TNF $\alpha$ on growth factor production. Insulin was used as a positive control in the NIL8 bioassay (Figure 7A). TNF $\alpha$ and IL-17 at the maximum possible concentration remaining in the conditioned medium had no significant effect on growth/survival of the NIL8 cells, showing that the growth factor activity was not attributable to residual TNF $\alpha$ plus IL-17 (Figure 7B).

As noted above, TNF $\alpha$ transactivates the EGF receptor (EGFR) in HT-29 cells, and this effect is augmented by IL-17 [30,37]. The TNF $\alpha$-elicited component of this effect is reported to involve release of the EGFR ligand transforming growth factor- $\alpha$ (TGF- $\alpha$ ) and its subsequent activation of EGFR [37]. Thus, it was possible that the growth factor activity detected in the NIL8 bioassay corresponded to EGFR ligand(s) released by the HT-29 cells in response to TNF $\alpha$ plus IL-17. To determine whether this was the case, we examined the effect of the selective EGFR tyrosine kinase inhibitor AG1478 on activity of the HT-29-derived growth factor in NIL8 cells (Figure 7C). As controls we used EGF, which acts entirely via EGFR, and insulin, which at high concentrations acts via the insulin receptor (IR) and IGF receptor1 (IGFR1) [54]. As expected, AG1478 strongly inhibited EGF action in the NIL8 cells, with $50 \%$ inhibition observed at $100 \mathrm{nM}$ AG1478 (Figure 7C). In contrast, AG1478 at higher concentrations weakly inhibited insulin signaling, presumably due to non-specific inhibition of IR and IGFR1 tyrosine kinase activity. The AG1478 inhibition curve for the activity produced by HT-29 cells was identical to that of insulin, indicating that this growth factor does not act primarily through EGFR (Figure 7C).

\section{Discussion}

Chronic inflammation is a well-known risk factor for colorectal cancer, but molecular mechanisms underlying the effects of inflammation on carcinogenesis are incompletely understood. Procarcinogenic effects of cytokines produced by inflammatory cells are thus of considerable interest. TNF $\alpha$ and IL-17 are commonly found together in the context of both acute and chronic inflammation; therefore, the effects of TNF $\alpha+$ IL-17 are biologically relevant to the inflammation-cancer interface. The present results show that TNF $\alpha$ and IL-17 synergistically stimulate glycolysis and growth factor production by human colorectal cancer cells, effects that could contribute to the positive effect of inflammation on carcinogenesis.

The transcription factor HIF- $1 \alpha$ is a master regulator of genes encoding components of the glycolytic pathway, and c-myc also positively regulates some of these genes. 

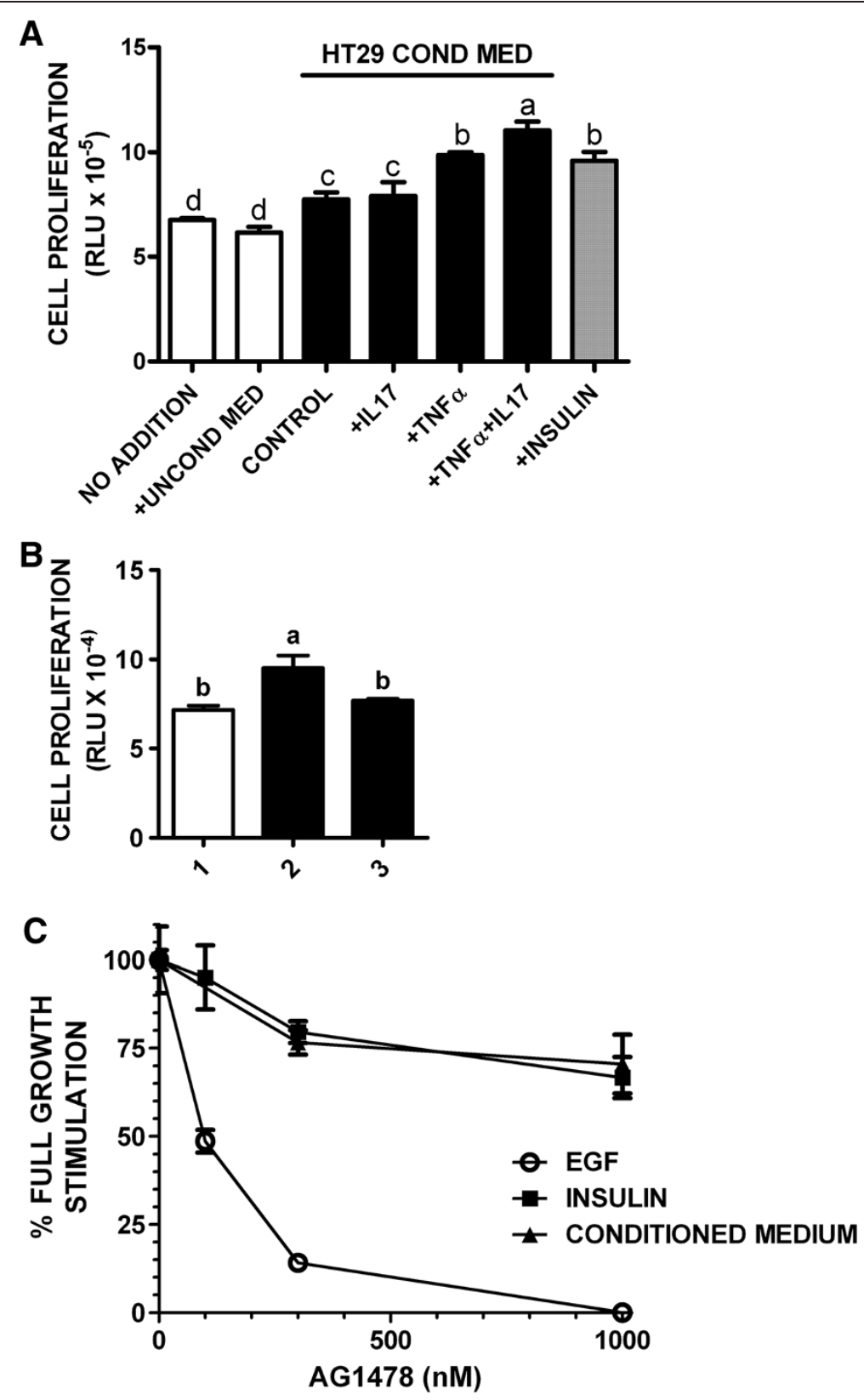

Figure 7 Medium conditioned by HT-29 cells treated with TNFa and IL-17 stimulates growth/survival of NIL8 cells. (A). NIL8 cells were treated for $24 \mathrm{~h}$ with nothing, or $10 \mu \mathrm{l}$ unconditioned medium (open bars), or insulin $(1 \mu \mathrm{g} / \mathrm{ml}$ ) (filled gray bar), or $10 \mu \mathrm{l}$ of medium conditioned by cultures of HT-29 cells treated with vehicle (control), TNFa, IL-17, or TNFa + IL-17 (filled black bars). Cell growth/survival of the NIL8 cells was then assayed (Methods). Each bar is the mean of quadruplicate assays \pm SE. Means with different letters were significantly different, $P<0.05$. (B). Cell growth/survival of NIL8 cells treated with: Bar 1: unconditioned McCoys 5A medium; Bar 2: medium conditioned by HT-29 cells stimulated with $25 \mathrm{ng} / \mathrm{ml}$ TNFa + $50 \mathrm{ng} / \mathrm{ml} \mathrm{IL-17}$ for $24 \mathrm{~h}$; Bar 3: unconditioned medium containing $25 \mathrm{ng} / \mathrm{ml}$ TNFa $+50 \mathrm{ng} / \mathrm{ml} \mathrm{IL-17.} \mathrm{Means} \mathrm{with} \mathrm{different} \mathrm{letters} \mathrm{were} \mathrm{significantly}$ different, $P<0.05$. (C). NIL8 cells were treated for $24 \mathrm{~h}$ with EGF $(300 \mathrm{ng} / \mathrm{ml})(0)$, insulin $(10 \mu \mathrm{g} / \mathrm{ml})(\mathbf{m})$, or $10 \mu \mathrm{l}$ of medium conditioned by HT-29 cells stimulated with TNFa + IL-17 ( $\mathbf{\Delta})$, plus increasing concentrations of AG1478. Cell growth/survival vs. unstimulated control NIL8 cells was then assayed (Methods). Data were plotted as \% growth stimulation observed in the absence of AG1478. Results show the means of quadruplicate assays \pm SE.

TNF $\alpha$ cooperatively induced the expression of both HIF- $1 \alpha$ and c-myc in HT-29 cells. Of particular interest, the effect of TNF $\alpha$ and IL-17 on HIF- $1 \alpha$ was synergistic and therefore resembled the synergistic effect of the two cytokines on glycolysis in HT-29, T84 and Caco-2 cells
(Figure 1A,C,D,E). We initially hypothesized, therefore, that HIF- $1 \alpha$ produced in response to TNF $\alpha$ plus IL-17 might globally induce transcription of genes encoding components of the glycolytic pathway, and that c-myc might also contribute to this induction. To test this idea 
the effects of TNF $\alpha$ and IL-17 on expression of six components and one regulator of the glycolytic pathway were examined. The genes encoding all seven proteins are known targets of HIF-1 $\alpha[12,41-43]$, and three of them (SLC2A1, HK2 and LDHA) are also well-documented targets of c-myc [13-15]. Surprisingly, TNF $\alpha$ and IL-17 selectively induced expression of SLC2A1 and HK2 but did not regulate the expression of SLC2A3, ENO1, PKM2, LDHA, or PFKFB3. The glucose transporter SLC2A1 (also known as Glut1) facilitates the uptake of glucose, and HK2 catalyzes the first step in glycolysis, phosphorylation of D-glucose to yield D-glucose-6-phosphate.

HIF- $1 \alpha$ was initially identified as a mediator of effects of hypoxia, and these effects vary in a cell type-specific manner. Relevant to the present results, selective induction of $\mathrm{HK} 2$ and pyruvate dehydrogenase kinase-1 (PDK1) by hypoxia (and HIF-1 $\alpha$ and c-myc) was observed in a previous study of human P493-6 B-lymphoblastoid cells, a model for human Burkitt's lymphoma [55]. In these cells, several other putative HIF- $1 \alpha / \mathrm{c}$-myc targets including ENO1 and LDHA were not regulated by hypoxia, HIF- $1 \alpha$ or c-myc [55]. Similarly, in MCF7 breast cancer cells SLC2A1, HK2, and PFKFB3 but not ENO1 or LDHA were strongly induced by hypoxia [56]. In contrast, hypoxia and HIF- $1 \alpha$ induced expression of ENO1 and LDHA in another human cancer cell line, HEP3B hepatoma cells $[57,58]$. The difference in response of various HIF- $1 \alpha$ target genes to changes in HIF-1 $\alpha$ observed in different cancer cell lines remains to be investigated further. Possible explanations include higher or lower affinities of different binding sites for HIF-1 $\alpha$, sequence context or chromatin configuration of the binding sites, different basal levels of expression of HIF-1 $\alpha$ target genes in different cancer cells, or differences in experimental protocols from study to study.

The PI3K-AKT signaling pathway plays an important role in regulating HIF- $1 \alpha$ expression in cancer [13] and in response to growth factors [16,17]. In the present study AKT was activated in response to TNF $\alpha$ but not IL-17. This activation of AKT was largely mediated by EGFR transactivation, as it was strongly inhibited by the selective EGFR tyrosine kinase inhibitor AG1478. However, AG1478 had a minimal effect on stimulation of glycolysis by TNF $\alpha+$ IL-17 (Figure 1F), that resembled the $\sim 25 \%$ non-specific inhibition by $1 \mu \mathrm{M}$ AG1478 of receptor tyrosine kinases other than EGFR (Figure 7C). This indicates that signaling events other than EGFR transactivation play an important role in induction of glycolysis by TNF $\alpha+$ IL-17.

Chetomin is a low molecular weight compound produced by the mold Chaetomium cochliodes that inhibits transcriptional activation by HIF-1 $\alpha$ [45]. Chetomin elicited a dose-dependent partial inhibition of TNF $\alpha$ plus IL-17-stimulated lactate production, which correlated with inhibition of SLC2A1 but not HK2 induction. The effective chetomin dose range and degree of inhibition of cytokine-stimulated SLC2A1 expression was remarkably similar to that seen for inhibition by chetomin of hypoxia-stimulated expression of two other HIF- $1 \alpha$ targets, CA9 and VEGF, in HT1080 human fibrosarcoma cells [46]. The results presented here therefore suggest that HIF-1 $\alpha$-mediated induction of SLC2A1 plays a role in the stimulation of glycolysis by TNF $\alpha+$ IL-17. The SLC $2 A 1$ gene has been shown previously to be a HIF-1 $\alpha$ target , and ChIP-Seq and ChIP-Chip analysis has identified a HIF-1 $\alpha$ binding site upstream of the SLC2A1 gene [59-61].

IL-17 synergizes with TNF $\alpha$ to induce expression of chemokines such as CXCL1, CXCL8, and CCL20 in HT29 and other cells [30]. Major mechanisms for this induction are activation of the canonical NF- $\kappa B$ signaling pathway by $\mathrm{TNF} \alpha$, resulting in increased chemokine gene transcription, and IL-17-mediated stabilization of chemokine mRNAs [31,32]. The possibility was therefore considered that NF- $\mathrm{kB}$ might play a role in the induction of glycolysis by TNF $\alpha+$ IL-17. The protein kinase IKK $\beta$ is a key component of the canonical NF- $\mathrm{kB}$ signaling pathway, and TPCA-1 is a selective inhibitor of IKK $\beta$ [50]. Interestingly, TPCA-1 strongly inhibited TNF $\alpha$ plus IL-17-stimulated lactate production and induction of $\mathrm{HK} 2$ but not SLC2A1. These results suggest that NF- $\mathrm{KB}$ -mediated induction of $\mathrm{HK} 2$ plays a role in the stimulation of glycolysis by TNF $\alpha+$ IL-17. The ENCODE project has accomplished human genome-wide mapping of binding sites for NF- $\mathrm{B}$ and a number of other transcription factors [62]. The results of the ENCODE project are now displayed in the human genome database (http://genome.ucsc.edu). Within intron 1 of the HK2 gene, there is a sequence that is bound by NF- $\kappa B$ in four human lymphoblastoid cell lines and that maps to a DNase-1 hypersensitive site. In the current assembly (hg19) of the human genome sequence, the coordinates for this sequence are chr 2: 75076257-75076681. This interval contains a sequence on the opposite strand $5^{\prime}$ GGGGCATTCC-3', which agrees with the consensus NF- $\kappa B$ binding sequence GGGRNNYYCC [63]. It is possible that this site might play a role in induction of $\mathrm{HK} 2$ expression by TNF $\alpha+$ IL-17.

Evidence indicates that cancer-associated fibroblasts (CAF) and tumor cells form a reciprocal positive feedback loop in which tumor cells produce factors that promote activation, proliferation, and chemotaxis of CAF, which in turn produce factors that enhance tumor cell proliferation [33-36]. The results presented here demonstrate that IL17 synergizes with TNF $\alpha$ to stimulate the production by HT-29 cells of a factor that increases proliferation/survival of fibroblastic cells. Similar to the effect of TNF $\alpha$ and IL17 on glycolysis, IL-17 alone did not affect production of the factor but it significantly enhanced TNF $\alpha$-stimulated 
factor production. This factor does not appear to act primarily via EGFR, and its identity remains to be investigated.

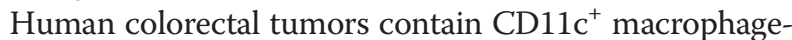
like cells that produce TNF $\alpha$ [29], and Th17 cells that produce IL-17 [26,27]; thus, the two cytokines are both expressed in colorectal tumors. Moreover, increased TNF $\alpha$ expression is correlated with increased diameter and extent of primary tumors [29], and studies of mouse models have indicated that IL-23/IL-17 signaling plays a key role in colorectal tumor development [28]. In the present study we investigated mechanisms for the apparent procarcinogenic effect of TNF $\alpha$ and IL-17.

\section{Conclusions}

Based on the results presented here, stimulation of glycolysis and growth factor production are two mechanisms by which TNF $\alpha$ and IL-17 might cooperate in promoting colorectal carcinogenesis.

\section{Methods \\ Materials}

Human recombinant TNF $\alpha$ (210-TA) and IL-17A (317-IL) were from R\&D Systems. Anti-PKM2 mouse monoclonal antibody (5D2-3B3) and anti-SLC2A1 and SLC2A3 polyclonal antibodies used for Western blotting were from Millipore. All other primary antibodies used for Western blotting were from Cell Signaling Technology. HRPconjugated secondary antibodies for Western blotting were from Vector Laboratories. SuperSignal West Pico Chemiluminescent Substrate, obtained from Thermo Scientific, was used for detection of HRP-secondary antibodies in Western blots. Chetomin, TPCA-1, and AG1478 were from Sigma-Aldrich. The glucose (HK) detection reagent was from Sigma-Aldrich (\#G3293). Rabbit muscle lactate dehydrogenase $(25 \mathrm{kU} / \mathrm{mg})$ used for assaying L-lactate was from EMD Millipore.

\section{Cell culture}

Human colorectal cancer (CRC) cell lines HT-29, T84, HCT119, and Caco-2 were cultured at $37 \mathrm{C}$ in McCoy's 5A medium supplemented with $15 \mathrm{mM}$ HEPES, 10\% FBS, penicillin $(100 \mathrm{U} / \mathrm{ml})$ and streptomycin $(100 \mu \mathrm{g} / \mathrm{ml})$. The NIL8 hamster fibroblastic cell line [51-53] was cultured in MEM supplemented with 10\% FBS, nonessential amino acids, penicillin $(100 \mathrm{U} / \mathrm{ml})$ and streptomycin $(100 \mu \mathrm{g} / \mathrm{ml})$. Cell counts were performed with a hemocytometer.

\section{Glucose utilization, lactate production, and growth factor experiments}

CRC cells were plated at a density of $2 \times 10^{6}$ cells per $3.5 \mathrm{~cm}$ diameter well (6 well plates) in McCoy's 5A medium with $10 \%$ FBS and antibiotics. After 48 hours the medium was changed to serum-free McCoys 5A with antibiotics, and cells were cultured for an additional $24 \mathrm{~h}$. At this time the cells had grown to confluent monolayers. The medium was aspirated, and the cultures were washed once with PBS. Fresh serum-free McCoys 5A medium plus antibiotics was then added to each well. TNF $\alpha$ (25 ng/ml), IL-17 (50 ng/ml), or vehicle was then added as indicated, and the cells were cultured for an additional $24 \mathrm{~h}$. The medium was then harvested and stored at $-80 \mathrm{C}$ prior to being assayed for glucose, L-lactate, or growth factor activity.

\section{Glucose and L-lactate assays}

For assaying the concentration of D-glucose in culture media, the glucose (HK) assay reagent (Sigma-Aldrich \#G3293) was utilized. This method uses two enzymes, hexokinase and glucose-6-phosphate dehydrogenase. Hexokinase first catalyzes conversion of D-glucose to glucose-6-phosphate. Glucose-6-phosphate dehydrogenase then catalyzes the reaction of glucose-6-phosphate and $\mathrm{NAD}^{+}$to produce 6-phosphogluconate and NADH. Progress of the reaction was monitored spectrophotometrically by measuring production of NADH, which absorbs light at $340 \mathrm{~nm}$. The concentration of glucose was determined using a standard curve. The concentration of D-glucose in McCoy's $5 \mathrm{~A}$ medium is $3 \mathrm{mg} / \mathrm{ml}$. Glucose utilized by the cells during the $24 \mathrm{~h}$ incubation period was calculated as the difference between the starting glucose concentration (i.e. in medium not incubated with cells) and the final glucose concentration in medium incubated with cells, and was expressed as a percentage of the starting concentration.

The production of L-lactate by cultured cells was assayed enzymatically with rabbit muscle lactate dehydrogenase (EMD Millipore Corp, $25 \mathrm{kU} / \mathrm{mg}$ ), as described in ref. [64]. The starting medium, serum-free McCoy's 5A, does not contain L-lactate. The concentration of L-lactate in medium after cell culture was determined using a standard curve.

\section{Growth factor assays}

Bioassays of growth factor activity in cell culture media were performed using the NIL8 hamster fibroblastic cell line, which responds to a variety of growth factors that are active in fibroblasts [51-53]. The Lonza ViaLight Plus cell proliferation kit was used for these assays. The kit measures the amount of ATP in monolayer cultures and therefore measures cell proliferation/survival. Briefly, NIL8 cells were plated in 96 well cell culture plates in MEM plus $0.3 \%$ serum, non-essential amino acids and antibiotics. After $24 \mathrm{~h}$, additions of cell culture medium samples were made as indicated. The cells were then incubated for $24 \mathrm{~h}$, lysed, and the amount of ATP per well was determined using the manufacturer's protocol. Insulin, which 
stimulates DNA synthesis in NIL8 cells [51-53], was used as a positive control.

\section{Protein expression experiments and AKT phosphorylation assays}

The effect of cytokines on expression of specific cellular proteins and on AKT phosphorylation was determined by Western blot analysis of whole cell extracts by standard methods as described previously [65]. Cells were plated in $6 \mathrm{~cm}$ dishes at a density of $5-7 \times 10^{6} \mathrm{cells} /$ dish, and the cultures were incubated at $37 \mathrm{C}$ until confluent. The cultures were washed with PBS, fresh serum-free medium was added, and the cultures were incubated for $24 \mathrm{~h}$ at $37 \mathrm{C}$. TNF $\alpha(25 \mathrm{ng} / \mathrm{ml})$ and/or IL-17 $(50 \mathrm{ng} / \mathrm{ml})$, or vehicle (control cultures), was then added, and incubation was continued for the time indicated. The NETN extraction buffer [65] used for preparing cell extracts was supplemented with a protease inhibitor mix obtained from Sigma-Aldrich (\#P8340) and phosphatase inhibitors sodium fluoride, disodium $\beta$-glycerophosphate , sodium pyrophosphate, and sodium vanadate. In all experiments the concentration of protein in each cell extract was determined by the method of Lowry [66], and 30 or $60 \mu \mathrm{g}$ of extract protein was loaded in each lane of the gel. For Western blot analysis of SLC2A1 expression, samples were not boiled prior to loading the gels, to prevent aggregation of SLC2A1 protein [67]. For measurements of AKT phosphorylation, Western blots were probed with monoclonal antibodies that specifically recognize phospho-AKT (Ser473) or total AKT (Cell Signaling \#4060S and \#4691S). Methods for blotting the gels and probing the blots were as described previously [65].

\section{Statistics}

The unpaired $t$-test was used for comparison of two means. For comparison of more than two means, data were subjected to one-way ANOVA followed by the Student-Newman-Keuls multiple comparison test. Linear regression analysis was performed for evaluation of inhibitor data, with $P<0.05$ used as a cut-off for significance of a downward trend in assay result plotted as a function of increasing inhibitor concentration.

\section{Abbreviations \\ TNFa: Tumor necrosis factor a; IL-17: Interleukin 17; HIF-1a: Hypoxia inducible factor 1a; NF-KB: Nuclear factor KB; HK2: Hexokinase-2; ENO1: Enolase-1; PKM2: Pyruvate kinase M2; LDHA: Lactate dehydrogenase A; PFKFB3: 6-phoshofructo-2-kinase/fructose-2,6-bisphosphatase isoform 3; PI3K: Phosphatidylinositol 3-kinase; EGFR: Epidermal growth factor receptor; CAF: Stromal cancer-associated fibroblasts.}

\section{Competing interests}

The authors declare that they have no competing interests.

\section{Acknowledgments}

I thank K. DeFea and C. Lytle and F. Sladek for helpful discussions during the course of this project.
Received: 22 March 2013 Accepted: 8 July 2013

Published: 17 July 2013

\section{References}

1. Grivennikov SI, Greten FR, Karin M: Immunity, inflammation, and cancer. Cell 2010, 140:883-899.

2. Trinchieri G: Cancer and inflammation: an old intuition with rapidly evolving new concepts. Annu Rev Immunol 2012, 30:677-706.

3. Jemal A, Siegel R, Xu J, Ward E: Cancer statistics. CA Canc J Clin 2010, 60:277-300.

4. Terzić J, Grivennikov S, Karin E, Karin M: Inflammation and colon cancer. Gastroenterology 2010, 138:2101-2114.

5. Ullman TA, Itzkowitz SH: Intestinal inflammation and cancer. Gastroenterology 2011, 140:1807-1816.

6. Wang $D$, Dubois RN: The role of anti-inflammatory drugs in colorectal cancer. Annu Rev Med 2013, 64:131-144.

7. Vander Heiden MG, Cantley LC, Thompson CB: Understanding the Warburg effect: the metabolic requirements of cell proliferation. Science 2009, 324:1029-1033.

8. Hsu PP, Sabatini DM: Cancer cell metabolism: Warburg and beyond. Cell 2008, 134:703-707.

9. Kaelin WG Jr, Thompson CB: Q\&A: Cancer: clues from cell metabolism. Nature 2010, 465:562-564.

10. Hirschhaeuser F, Sattler UG, Mueller-Klieser W: Lactate: a metabolic key player in cancer. Cancer Res 2011, 71:6921-6925.

11. Semenza GL: HIF-1: upstream and downstream of cancer metabolism. Curr Opin Genet Dev 2010, 20:51-56.

12. Semenza GL: Defining the role of hypoxia-inducible factor 1 in cancer biology and therapeutics. Oncogene 2010, 29:625-634.

13. DeBerardinis RJ, Lum JJ, Hatzivassiliou G, Thompson CB: The biology of cancer: metabolic reprogramming fuels cell growth and proliferation. Cell Metab 2008, 7:11-20.

14. Osthus RC, Shim H, Kim S, Li Q, Reddy R, Mukherjee M, Xu Y, Wonsey D, Lee LA, Dang CV: Deregulation of glucose transporter 1 and glycolytic gene expression by c-Myc. J Biol Chem 2000, 275:21797-21800.

15. Kim JW, Zeller KI, Wang Y, Jegga AG, Aronow BJ, O'Donnell KA, Dang CV: Evaluation of myc E-box phylogenetic footprints in glycolytic genes by chromatin immunoprecipitation assays. Mol Cell Biol 2004, 24:5923-5936.

16. Treins C, Giorgetti-Peraldi S, Murdaca J, Semenza GL, Van Obberghen E: Insulin stimulates hypoxia-inducible factor 1 through a phosphatidylinositol 3-kinase/target of rapamycin-dependent signaling pathway. J Biol Chem 2002, 277:27975-27981.

17. Zhong H, Chiles K, Feldser D, Laughner E, Hanrahan C, Georgescu MM, Simons JW, Semenza GL: Modulation of hypoxia-inducible factor 1alpha expression by the epidermal growth factor/phosphatidylinositol 3-kinase /PTEN/AKT/FRAP pathway in human prostate cancer cells: implications for tumor angiogenesis and therapeutics. Cancer Res 2000, 60:1541-1545.

18. Scharte M, Han X, Bertges DJ, Fink MP, Delude RL: Cytokines induce HIF-1 DNA binding and the expression of HIF-1-dependent genes in cultured rat enterocytes. Am J Physiol Gastrointest Liver Physiol 2003, 284:G373-G384.

19. Jiang $H$, Zhu YS, Xu H, Sun Y, Li QF: Inflammatory stimulation and hypoxia cooperatively activate HIF-1\{alpha\} in bronchial epithelial cells: involvement of PI3K and NF-\{kappa\}B. Am J Physiol Lung Cell Mol Physiol 2010, 298:L660-L669.

20. Hot A, Zrioual S, Lenief V, Miossec P: IL-17 and tumour necrosis factor a combination induces a HIF-1a-dependent invasive phenotype in synoviocytes. Ann Rheum Dis 2012, 71:1393-1401.

21. Ford AC, Sandborn WJ, Khan KJ, Hanauer SB, Talley NJ, Moayyedi P: Efficacy of biological therapies in inflammatory bowel disease: systematic review and meta-analysis. Am J Gastroenterol 2011, 106:644-659.

22. Pearson $\mathrm{C}$, Uhlig HH, Powrie F: Lymphoid microenvironments and innate lymphoid cells in the gut. Trends Immunol 2012, 33:289-296.

23. Cherrier M, Ohnmacht C, Cording S, Eberl G: Development and function of intestinal innate lymphoid cells. Curr Opin Immunol 2012, 24:277-283.

24. Sallusto F, Zielinski CE, Lanzavecchia A: Human Th17 subsets. Eur J Immunol 2012, 42:2215-2220.

25. Geremia A, Jewell DP: The IL-23/IL-17 pathway in inflammatory bowel disease. Expert Rev Gastroenterol Hepatol 2012, 6:223-237.

26. Su X, Ye J, Hsueh EC, Zhang Y, Hoft DF, Peng G: Tumor microenvironments direct the recruitment and expansion of human Th17 cells. J Immunol 2010, 184:1630-1641.

27. Tosolini M, Kirilovsky A, Mlecnik B, Fredriksen T, Mauger S, Bindea G, Berger A, Bruneval P, Fridman WH, Pagès F, Galon J: Clinical impact of different 
classes of infiltrating T cytotoxic and helper cells (Th1, th2, treg, th17) in patients with colorectal cancer. Cancer Res 2011, 71:1263-1271.

28. Grivennikov SI, Wang K, Mucida D, Stewart CA, Schnabl B, Jauch D, Taniguchi K, Yu GY, Osterreicher CH, Hung KE, Datz C, Feng Y, Fearon ER, Oukka M, Tessarollo L, Coppola V, Yarovinsky F, Cheroutre H, Eckmann L, Trinchieri G, Karin M: Adenoma-linked barrier defects and microbial products drive IL-23 /IL-17-mediated tumour growth. Nature 2012, 49:254-258.

29. Numata A, Minagawa T, Asano M, Nakane A, Katoh H, Tanabe T: Functional evaluation of tumor-infiltrating mononuclear cells. Detection of endogenous interferon-gamma and tumor necrosis factor-alpha in human colorectal adenocarcinomas. Cancer 1991, 68:1937-1943.

30. Lee JW, Wang P, Kattah MG, Youssef S, Steinman L, DeFea K, Straus DS: Differential regulation of chemokines by IL-17 in colonic epithelial cells. J Immunol 2008, 181:6536-6545.

31. Hamilton T, Li X, Novotny M, Pavicic PG Jr, Datta S, Zhao C, Hartupee J, Sun $D:$ Cell type- and stimulus-specific mechanisms for post-transcriptional control of neutrophil chemokine gene expression. J Leukoc Biol 2012, 91:377-383

32. Weinberg RA: The Biology of Cancer. New York, NY: Garland Science; 2007:527-556.

33. Räsänen K, Vaheri A: Activation of fibroblasts in cancer stroma. Exp Cell Res 2010, 316:2713-2722.

34. Allen $\mathrm{M}$, Louise Jones J: Jekyll and Hyde: the role of the microenvironment on the progression of cancer. J Pathol 2011, 223:162-176.

35. Cirri P, Chiarugi P: Cancer-associated-fibroblasts and tumour cells: a diabolic liaison driving cancer progression. Cancer Metastasis Rev 2012, 31:195-208.

36. Hwang RF, Moore TT, Hattersley MM, Scarpitti M, Yang B, Devereaux E, Ramachandran V, Arumugam T, Ji B, Logsdon CD, Brown JL, Godin R: Inhibition of the hedgehog pathway targets the tumor-associated stroma in pancreatic cancer. Mol Canc Res 2012, 10:1147-1157.

37. Janes KA, Gaudet S, Albeck JG, Nielsen UB, Lauffenburger DA, Sorger PK: The response of human epithelial cells to TNF involves an inducible autocrine cascade. Cell 2006, 124:1225-1239.

38. Boerner P, Resnick RJ, Racker E: Stimulation of glycolysis and amino acid uptake in NRK-49F cells by transforming growth factor beta and epidermal growth factor. Proc Natl Acad Sci USA 1985, 82:1350-1353.

39. Conricode KM, Ochs RS: Epidermal growth factor and 12-0 -tetradecanoylphorbol 13-acetate stimulate lactate production and the pentose phosphate pathway in freshly isolated rat hepatocytes. J Biol Chem 1990, 265:20931-20937.

40. Daub H, Weiss FU, Wallasch C, Ullrich A: Role of transactivation of the EGF receptor in signalling by G-protein-coupled receptors. Nature 1996, 379:557-560.

41. Rozengurt $\mathrm{E}:$ Mitogenic signaling pathways induced by $\mathrm{G}$ proteincoupled receptors. J Cell Physiol 2007, 213:589-602.

42. Obach M, Navarro-Sabaté A, Caro J, Kong X, Duran J, Gómez M, Perales JC, Ventura F, Rosa JL, Bartrons R: 6-Phosphofructo-2-kinase (pfkfb3) gene promoter contains hypoxia-inducible factor-1 binding sites necessary for transactivation in response to hypoxia. J Biol Chem 2004, 279:53562-53570.

43. Xia X, Kung AL: Preferential binding of HIF-1 to transcriptionally active loci determines cell-type specific response to hypoxia. Genome Biol 2009, 10:R113.

44. Schödel J, Oikonomopoulos S, Ragoussis J, Pugh CW, Ratcliffe PJ, Mole DR: High-resolution genome-wide mapping of HIF-binding sites by ChIP-seq. Blood 2011, 117:e207-e217

45. Kung AL, Zabludoff SD, France DS, Freedman SJ, Tanner EA, Vieira A, Cornell-Kennon S, Lee J, Wang B, Wang J, Memmert K, Naegeli HU, Petersen F, Eck MJ, Bair KW, Wood AW, Livingston DM: Small molecule blockade of transcriptional coactivation of the hypoxia-inducible factor pathway. Canc Cell 2004, 6:33-43.

46. Staab A, Loeffler J, Said HM, Diehlmann D, Katzer A, Beyer M, Fleischer M, Schwab F, Baier K, Einsele H, Flentje M, Vordermark D: Effects of HIF-1 inhibition by chetomin on hypoxia-related transcription and radiosensitivity in HT 1080 human fibrosarcoma cells. BMC Canc 2007, 7:213.

47. Elewaut D, DiDonato JA, Kim JM, Truong F, Eckmann L, Kagnoff MF: NF-kappa B is a central regulator of the intestinal epithelial cell innate immune response induced by infection with enteroinvasive bacteria. J Immunol 1999, 163:1457-1466.

48. Rosenstiel P, Fantini M, Bräutigam K, Kühbacher T, Waetzig GH, Seegert D, Schreiber S: TNF-alpha and IFN-gamma regulate the expression of the
NOD2 (CARD15) gene in human intestinal epithelial cells. Gastroenterology 2003, 124:1001-1009.

49. Vallabhapurapu S, Karin M: Regulation and function of NF-kappaB transcription factors in the immune system. Annu Rev Immunol 2009, 27:693-733.

50. Sutcliffe AM, Clarke DL, Bradbury DA, Corbett LM, Patel JA, Knox AJ: Transcriptional regulation of monocyte chemotactic protein-1 release by endothelin-1 in human airway smooth muscle cells involves NF-kappaB and AP-1. Br J Pharmacol 2009, 157:436-450.

51. Straus DS, Pang KJ: Effects of bradykinin on DNA synthesis in resting NIL8 hamster cells and human fibroblasts. Exp Cell Res 1984, 151:87-95.

52. Hylka WW, Teplow DB, Kent SB, Straus DS: Identification of a peptide fragment from the carboxyl-terminal extension region (E-domain) of rat proinsulin-like growth factor-II. J Biol Chem 1985, 260:14417-14420.

53. Straus DS, Coppock DL, Pang KJ: Low molecular weight mitogenic factor produced by BRL-3A cultured rat liver cells. Biochem Biophys Res Commun 1981, 100:1619-1625.

54. Straus DS: Growth-stimulatory actions of insulin in vitro and in vivo. Endocr Rev 1984, 5:356-369.

55. Kim JW, Gao P, Liu YC, Semenza GL, Dang CV: Hypoxia-inducible factor 1 and dysregulated c-Myc cooperatively induce vascular endothelial growth factor and metabolic switches hexokinase 2 and pyruvate dehydrogenase kinase 1. Mol Cell Biol 2007, 27:7381-7393.

56. Elvidge GP, Glenny L, Appelhoff RJ, Ratcliffe PJ, Ragoussis J, Gleadle JM: Concordant regulation of gene expression by hypoxia and 2 oxoglutarate-dependent dioxygenase inhibition: the role of HIF-1alpha, HIF-2alpha, and other pathways. J Biol Chem 2006, 281:15215-15226.

57. Semenza GL, Jiang BH, Leung SW, Passantino R, Concordet JP, Maire P, Giallongo A: Hypoxia response elements in the aldolase A, enolase 1, and lactate dehydrogenase $A$ gene promoters contain essential binding sites for hypoxia-inducible factor 1. J Biol Chem 1996, 271:32529-32537.

58. Iyer NV, Kotch LE, Agani F, Leung SW, Laughner E, Wenger RH, Gassmann M, Gearhart JD, Lawler AM, Yu AY, Semenza GL: Cellular and developmental control of $\mathrm{O} 2$ homeostasis by hypoxia-inducible factor 1 alpha. Genes Dev 1998, 12:149-162.

59. Krieg AJ, Rankin EB, Chan D, Razorenova O, Fernandez S, Giaccia AJ: Regulation of the histone demethylase JMJD1A by hypoxia-inducible factor 1 alpha enhances hypoxic gene expression and tumor growth. Mol Cell Biol 2010, 30:344-353.

60. Mole DR, Blancher C, Copley RR, Pollard PJ, Gleadle JM, Ragoussis J, Ratcliffe PJ: Genome-wide association of hypoxia-inducible factor (HIF)-1alpha and HIF-2alpha DNA binding with expression profiling of hypoxia-inducible transcripts. J Biol Chem 2009, 284:16767-16775.

61. Mimura I, Nangaku M, Kanki Y, Tsutsumi S, Inoue T, Kohro T, Yamamoto S, Fujita T, Shimamura T, Suehiro J, Taguchi A, Kobayashi M, Tanimura K, Inagaki T, Tanaka T, Hamakubo T, Sakai J, Aburatani H, Kodama T, Wada Y: Dynamic change of chromatin conformation in response to hypoxia enhances the expression of GLUT3 (SLC2A3) by cooperative interaction of hypoxiainducible factor 1 and KDM3A. Mol Cell Biol 2012, 32:3018-3032.

62. Neph S, Vierstra J, Stergachis AB, Reynolds AP, Haugen E, Vernot B, Thurman RE, John S, Sandstrom R, Johnson AK, Maurano MT, Humbert R, Rynes E, Wang H, Vong S, Lee K, Bates D, Diegel M, Roach V, Dunn D, Neri J, Schafer A, Hansen RS, Kutyavin T, Giste E, Weaver M, Canfield T, Sabo P, Zhang M, Balasundaram G, Byron R, MacCoss MJ, Akey JM, Bender MA, Groudine M, Kaul R, Stamatoyannopoulos JA: An expansive human regulatory lexicon encoded in transcription factor footprints. Nature 2012, 489:83-90.

63. Hayden MS, Ghosh S: Signaling to NF-kappaB. Genes Dev 2004, 18:2195-2224.

64. Lundholm ML, Mohme-Lundholm E, Vamos N: Lactic acid assay with L (plus)lactic acid dehydrogenase from rabbit muscle. Acta Physiol Scand 1963, 58:243-249.

65. Campo PA, Das S, Hsiang CH, Bui T, Samuel CE, Straus DS: Translational regulation of cyclin D1 by 15-deoxy-delta(12,14)-prostaglandin $\mathrm{J}(2)$. Cell Growth Differ 2002, 13:409-420.

66. Lowry OH, Rosebrough NJ, Farr AL, Randall RJ: Protein measurement with the Folin phenol reagent. J Biol Chem 1951, 193:265-275.

67. Baldwin SA, Lienhard GE: Purification and reconstitution of glucose transporter from human erythrocytes. Methods Enzymol 1989, 174:39-50.

doi:10.1186/1476-4598-12-78

Cite this article as: Straus: TNFa and IL-17 cooperatively stimulate glucose metabolism and growth factor production in human colorectal cancer cells. Molecular Cancer 2013 12:78. 